\title{
Culture in the global economy: features of cultural goods on the threshold of a knowledge economy and increasing the country's competitiveness
}

\author{
Anna Koltsova ${ }^{1, *}$, Gennady Alpatov ${ }^{1}$, and Anna Volkova ${ }^{1}$ \\ ${ }^{1}$ St. Petersburg State University, Universitetskaya nab., 7-9, St. Petersburg, Russia
}

\begin{abstract}
The purpose of the article is to identify and analyze the problem areas of formation of values of cultural objects and further positioning of the territories in which they are located. Nowadays, approaches to the competitiveness of a market entity operating in the global economy have been changing dramatically due to the fact, that business has increased its role in a post-industrial society. The importance of marketing, especially in the field of culture, is considerably enhanced by the dominance of imperceptible assets inherent in the knowledge economy. However, the use of marketing involves taking into account the specifics of cultural practices. These practices manifest themselves at the level of understanding the nature of the cultural product as well as at pricing, promotion methods and mechanisms of distribution of cultural products to target consumer markets. The article uses the methodology of breakthrough positioning based on modified Cagan-Vogel maps and shows that since the culture is the "sphere of presence" of public interest, art objects cause growing competitiveness of territories where they are exhibited. The article substantiates the need for state participation in promoting cultural goods.
\end{abstract}

\section{Introduction}

Today, when business is increasingly beginning to work in the new economy radically changing approaches to the competitiveness of the market entity and the importance of marketing in the activities of organizations that provide services in the field of culture, is steadily increasing [1]. However, the use of marketing involves taking into account the specifics of cultural practices, manifested both at the level of understanding the nature of the product of culture, and setting prices, methods of promotion and mechanisms of distribution of cultural products to the target markets of consumers [2]. Culture performs the function of forming public consciousness, with the help of the sphere of culture, the state solves a lot of problems, creates jobs, increases the competitiveness of the country [3]. Culture as a branch of the economy nowadays attracts attention, especially since it is a "sphere of presence" of public interest.

\footnotetext{
*Corresponding author: $\underline{3 a 77 @ m a i l . r u}$
} 
The socio-cultural sphere as a subsystem of the national economy is characterized by a certain specificity of factors of production: the classical triad of J. B. Say is filled with content adequate to the sphere of culture. First of all, it concerns the personal factor, which is characterized by a high level of General and professional education. The share of workers with higher education in the cultural sector is higher than in the vast majority of economic sectors [4]. More because of certain specifics and the proportion of women in the composition of employees of this formation [5]. Much wider opportunities concurrently. At the same time and quality requirements provided by the cultural sector of services (including complimentary to the field of culture, educational, etc.) is higher than in other industries and activities.

Land and all that is in it, as a factor of production in the field of culture is less important than, for example, and agriculture or fuel and energy. However, the drivers of development in the field of culture are exceptions to this rule: national parks, protected areas and cultural monuments, etc. In General pursuant to the statement by A. Marshall that in a sense there are only two factors of production - nature and man, legitimate the following provision: in the cultural sphere, the personal factor is crucial. [6]

The sphere of culture, therefore - is an integral part of the national economy, the importance of which in modern conditions is steadily increasing. According to the Arts and Cultural Production Satellite Account (ACPSA), culture (arts and cultural economic activities) accounted for 4.2 percent of gross domestic product (GDP) in the United States, or $\$ 763.6$ billion. [7] Moreover, only from 2011 to 2015 the share of the cultural sphere in the US GDP grew by almost 1 percent (!).

According to the report of the British arts Council (ACE)29, English museums and galleries bring $£ 2,64$ billion a year and give 40 thousand people On the basis of the results of operations 2720 museums it is estimated that every $£ 1$ invested of public investment they are creating a $£ 3$ profit; $36 \%$ of all revenues bring museums funded by Central government, independent museums bring $25 \%$, and $11 \%$ comes from local museums. [8,9]

Even F. F. Rybakov in 1992 wrote that " for culture, its progressive development is of paramount importance to determine the boundaries between the market and non-market sectors." [10] and I must say, this border has not yet been found. The desire to commercialize many aspects of activity has negative consequences for the cultural sphere. Note that the availability of entertainment events should not be a "bargaining chip" in the implementation of pricing policy. On the other hand, in the market environment such cultural objects as museums, libraries (and even theaters) master additional functions and become educational and leisure centers focused on interactive communication.

\section{Methodology}

Analysis of strategies for the development of cultural objects can be made by analyzing such characteristics as the level of design (or style), as well as the level of technology (innovation component). Therefore, one of the promising strategies for the development of cultural brands of the territories is the strategy of breakthrough positioning. This strategy was modified for the art market, Margarita and Natalia Pashkus [11]. This strategy involves positioning the territories and art objects located on them in accordance with the matrix of breakthrough positioning (see Fig. 1) and in accordance with the characteristics of each of the "cells" are produced separate strategic recommendations. 


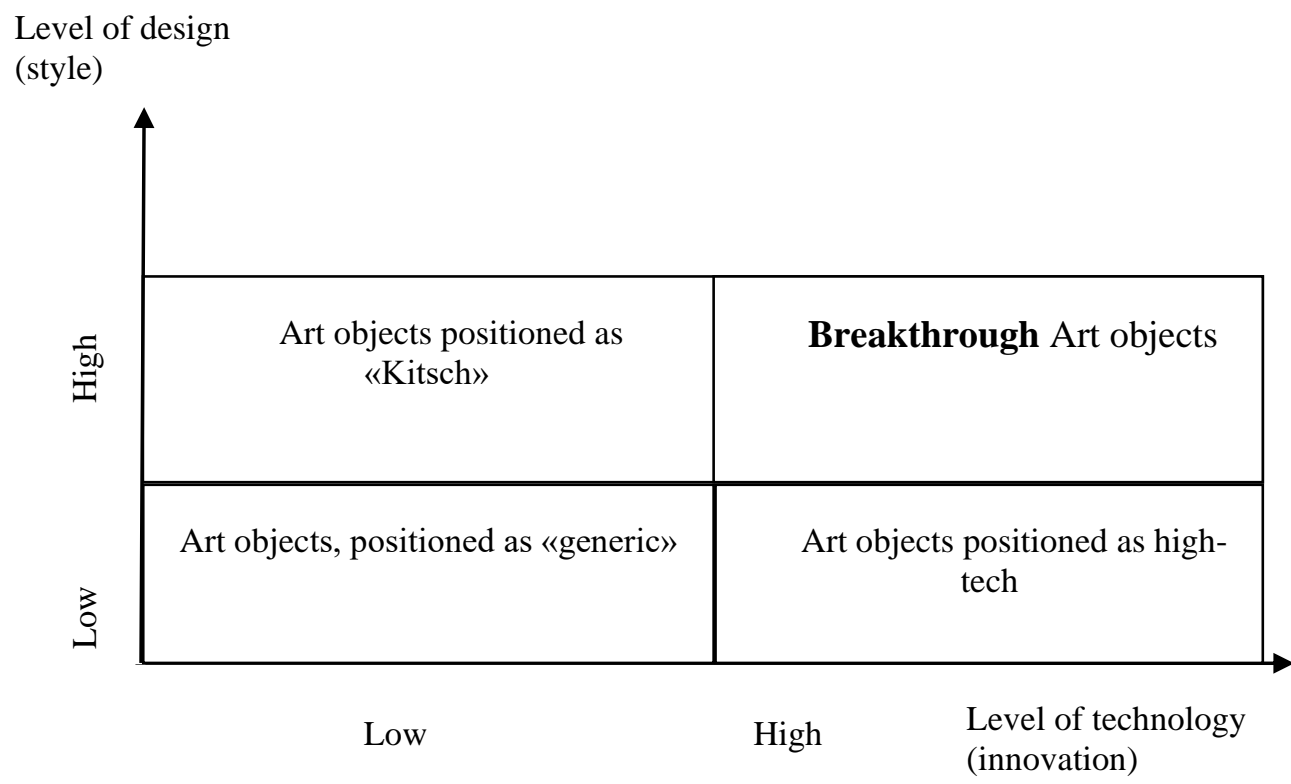

Fig. 1. Modified map positioning Cagan and Vogel

The four areas of the matrix correspond to four types of positioning strategies that territories can apply to build their competitive advantages and create a strong brand. In each category, the territory can develop quite successfully, however, the creation of a strong cultural brand and the formation of a global attraction is possible only when choosing the right landmarks and areas with high potential. Let's consider the main types of territory positioning strategies.

Art objects of generics do not have any pronounced components of technological or stylistic positioning. However, due to certain competitive advantages, they can be quite successful and perfectly typed (the famous Durer rabbit). Art objects of Kich try to "strike" the consumer with new meanings (from Marcel Duchamp to Salvador Dali). High-tech art objects actively use new opportunities (for example, the artist shouting at the picture at the time of its writing). Breakthrough facilities are more complex in nature, as there is a need to" close " the so-called SET-gap (and therefore meet the social need through new technologies and with satisfactory economic performance). With the right promotion, all positions have the potential to cause and/or support an existing brand territory [11].

Analysis of the properties of cultural goods as public and private and determines the uniqueness of the marketing offer of cultural goods. There is a specific phenomenon of cultural industries, when " the industry provides a ready set of both intended objects and ways of their assimilation... the list of objects offered for acquaintance, as a rule, is limited to a set of" consecrated" names and works that are considered as standards or replicated by mass culture " [12]. There is an adjustment of the mission of the Museum, respectively, changing ideas about the content of management in modern museums. Today, museums are included in the service industry, the tourism industry, in the program of development of territories, forming the image of the territory, making its own contribution to increasing its investment attractiveness. However, each Museum has the opportunity to create new Museum products using different tools, including information and communication technologies (virtual Museum concept) and implementing a multi-attributive product model; developing a flexible pricing policy; distributing the product into new market 
segments and latent market niches (cultural and educational campaign "night of the muses"), or implementing the concept of the third place.

Generic need of society becomes a common desire to optimize the time spent. In order to bring the provision of services of enterprises (institutions) of culture to international standards, it is necessary to move from the principle of pedestrian accessibility to the principle of transport accessibility. The future is to make the library, Museum, theater a new social space, the place where people want to be, just to meet, to communicate in their free time from household chores and work. The concept of "third place" also implies the creation of such a space. For each enterprise (institution) of culture, it is possible to construct a target audience through the construction of a private space.

\section{Results and Discussion}

The strategy of breakthrough positioning is well established in the art market. [13, 14] However, it is necessary to consider the specifics of these benefits. Features of management in the field of culture are dictated by the uniqueness of the benefits offered in the field of culture. Cultural products can be in material and non-material form (cognitive). Unlike physical products, the composition of a cultural product includes fundamentally different elements, for example, historical and cultural heritage, traditions, beliefs, norms, values, trademarks, brands, cultural goods, ideas, norms, etc. [12, 15] Consumption of various forms of experience often means more to people than the consumption of traditional goods and services.

The problem of applying the strategy is also caused by the fact that the results of the activities of institutions and organizations in the field of culture are benefits that occupy an intermediate position between public and private. A cultural good in General is a fully public good that can be classified as a mixed (communal) good. However, the sphere of culture generates a lot of private goods, which have special properties, revealed, for example, in the art market. Some cultural services may take the form of public goods, while others may take the form of private goods. Therefore, there is a need to take into account these properties in the development and implementation of public policy in the field of culture and the provision of targeted services that will allow the state to provide more or less equal access to the benefits of the cultural sphere and develop, through their use, unique competitive advantages both in the country (as a whole) and in different regions and even individual places.

It should be noted that public goods in the sphere of culture have a certain specificity. So, for example:

- Classification uncertainty. The greatest difficulty for the economy of culture is the lack of a common understanding of what should be attributed to the products of the sphere of culture, and what to the products of "related" industries. It should be noted that in the new economy and the expansion of cultural services, there is uncertainty about the status of a number of art objects (for example, it concerns contemporary art), which creates big problems, both in the analysis of the sphere of culture and in the positioning of its benefits. [16, 17]

- Information asymmetry. Cultural goods are characterized by a lack of reliable information about the properties of the service offered, as well as about alternative opportunities to meet the corresponding needs. There is no stable idea of their own needs, nor the ability of the art product to meet them. Information on the market of works of art (art market) is obviously biased, as it depends on subjective criteria, the "creative component". [18] in Addition, it is deliberately biased, as the market is interested in information substitution. The gap between expert and everyday representations gives rise to intermediaries (galleries, auction houses) for speculative 
actions to cheat prices and fashion formation. Today, popular in the art market, you can do anything, because the true value of a work of art know few specialists, and buyers for the most part can be guided only by their own intuition and assumptions.

- Uncertainty of outcome. The real result of cultural activity is formed after its completion: thus, the final result cannot be predetermined.

- Heterogeneity of cultural goods. A substantial part of the benefits of culture are heterogeneous and difficult to compare with each other. Competition is imperfect due to the uniqueness of the goods, limited art and confidentiality of transactions.

- Ideological component. The primary task of the cultural sphere is the preservation and development of the cultural potential and cultural heritage of the country. As long as the cultural sphere exists as a sociocultural phenomenon that preserves and reproduces historical and cultural symbols, the authorities, whether in democratic or authoritarian countries, will use cultural objects (such as museums and their exhibitions) to interpret the past and to construct projects for the future. [7, 19] working for the public interest opens wide access to public finances, allows to actively raise funds with the help of institutions of social responsibility of business. $[20,21]$

- Integration role. The promotion of cultural goods and ensuring their accessibility is also aimed at "ensuring the unity of the cultural space, equal opportunities for the inhabitants of the various territories of the country". [22] Culture is an integration symbol of the country, and the objects of the sphere of culture performs the function of forming public consciousness. Consequently, any Museum, in addition to historical or ethnographic, can take advantage of the presence of public interest and contribute to the solution of the problem of identity formation of different order (national, regional, etc.). On the examples of modern exhibition practice and based on the concept of B. Anderson [19] formulated the thesis that "the Museum and the map, as a tool of political power, are applicable to the ideological development of different types of collective identities" [23].

- The need for active promotion. The active role of the state is necessary for the implementation of the ideological component and the development of the integration role of the cultural sphere. The fact that many products created by the cultural sector and satisfy various needs in the cultural benefits, for the most part can be attributed to the special demand goods passive demand (the so-called meritoria benefits), by which we mean "good for which demand from the individuals behind the "desired society"" [24]. Therefore, there is a need for their active promotion with the help of social marketing tools.

The situation with private goods in the sphere of culture is a little easier, because their properties are well studied, for example, on the basis of the benefits of the art market. One of the most important specific features of a work of art as a commodity is the fact that the art market sells not so much the product itself as its image, reputation and prestige of owning it. [25] The Specificity of private goods in the sphere of culture is, first of all, especially works of art as a commodity:

- Non-utilitarianism. As a rule, cultural goods are not intended to meet physiological needs (according to A. Maslow), but only to meet social needs. Considering this feature of cultural goods, you can try to argue: after all, many antique items have a very specific utilitarian function (for example: furniture, utensils, weapons). However, when a cultural good as a work of art enters the art market, it has already passed the boundary between decorativeness and utilitarianism, when it is not the operational capabilities of the object that are important for the buyer, but its decorative, investment - non-utilitarian functions. It is also important to note that contrary to popular belief, not every item eventually begins to have antique value. 
- Lack of finiteness of consumption. Unlike most material objects, the art product does not have a clearly defined "shelf life". Undoubtedly, over time, any material object "wears out", but under optimal storage conditions and timely restorations, a work of art can live very, very long. For example, the wall paintings of the Great Egyptian pyramids of Giza or the temple in Deir El-Bahri with their original colors, not much tarnished for 35-45 centuries since the construction of these objects. Or, discovered near the Pyramid of Cheops, and exhibited on a specially created Museum site, Solar boats of Pharaoh Khufu, made of Lebanese cedar.

- Uniqueness. A work of art is by its nature an irreproducible product. This product cannot be restored, it can only be replaced. For example, " the restored Cathedral of Christ the Saviour in Moscow or the new Amber room in St. Petersburg will never acquire the value of originals." [12] Known attempts Renoir early in his career to compete with the machine in the manufacture of cooking utensils, which ended in an utter fiasco, as it is with all the talent and diligence could not create a fully identical items in the same set. Replicas and copies do not cease to be objects of purchase and sale in the art market, but the closest to the price of the original can come only the author's repetition, which refers to the question of pricing, when the value of the object is determined not only by its artistic merits (and often not so much), but depends on the name of the artist.

- Conditional evaluation. Like any material product of purchase and sale, an art object has a value. However, as stressed by A. V. Kolycheva, any quantitatively reasonable factors and pricing there may have only averaged nature, "since evaluation of this product as a piece of art, accompanies the effect of the extremes, keeping the balance of the price". [25] Note that the conventionality of evaluation is supported by the positioning of art as luxury goods. Traditional luxury items include works of art, which are rather luxury goods. Luxury goods (services) - "it is a material product (or service), which has a set of unique, exclusive functional and emotional characteristics (attributes). In the production of this product, elements of manual labor are used, its acquisition is regarded by the consumer as a status purchase; it can be inherited, the possession of it distinguishes the buyer from the General mass. Famous marketers Jose Luis Nueno and John A. Quelch "define luxury products as products for which the uncharacteristic dependence «functionality-price» but expressed quite explicitly the dependence of "intangible utility-price"". [27]

- The randomness of demand. This specificity is primarily due to the features of works of art as commercial values, as well as the complexity of the formation of prices for them: the demand for works of art is influenced by various subjective factors, in particular the model. [27, 28]

- Investment attractiveness (prospects). "The prospect of a work of art as a commodity is determined by the forecast, the identification of the current market conditions and the economic situation that characterizes the ratio of supply and demand."[29] However, the specificity of the art product is that, according to the established opinion in the art market, the observance of the conjuncture adversely affects the quality of the artwork. [7, 30] An artist striving for commercial success must constantly balance on the border between the true values of high art, the needs of the market and the demand that it dictates. [14] on the other hand, knowledge of market conditions allows you to sell the maximum possible amount of goods at the best prices and in the shortest possible time.

All of the above makes the use of a breakthrough positioning strategy quite problematic. However, without this strategy to develop into a global competitiveness is very difficult. 


\section{Conclusion}

It can be argued that the sphere of culture is gradually moving to an innovative path of development. Currently, there is a need to use fundamentally new approaches to the management of non-profit organizations in the sphere of culture. Such approaches include, for example, value-based management, which allows to take into account the specifics of cultural institutions and achieve good results. The relevance of this provision arises in connection with the active integration of cultural enterprises in the environment of egovernment and changing views on the profitability and efficiency of investments in this kind of activity.

It seems that the criterion for the validity of state support or commercial provision of the socio-cultural sphere should be the security of each citizen and society as a whole. State support is necessary primarily for the implementation of social marketing and ensuring free access of the population to the best domestic and world examples of culture and art.

In general, the direction of cultural reforms should be:

- development of cultural potential as a component of the country's competitiveness,

- implementation of structural reforms in cultural sectors aimed at improving the efficiency of financial, material and labor resources,

- improvement of models of functioning and development of the sphere of culture on the basis of multi-channel financing,

- $\quad$ expansion and active promotion of the social services market.

This article was prepared with the support of a grant for research at the expense of St. Petersburg State University "HUM_2018-2019: Art Market of St. Petersburg: between value and price".

\section{References}

1. M.A. Fox, Drive-in theatres, technology, and cultural change, Economics, Management, and Financial Markets 13, 24-39 (2018)

2. J. Bialynicka-Birula, Changes in the global art market, Oeconomia Copernicana 9, 695-714 (2018)

3. M. Sponte (Piştalu), Knowledge work and labor market performance: An empirical analysis, Journal of Self-Governance and Management Economics 6, 113-118 (2018)

4. K. Falkowski, Trade interdependence between Russia vs. the European Union and China within the context of the competitiveness of the Russian economy, Equilibrium. Quarterly Journal of Economics and Economic Policy 13, 667-687 (2018)

5. C. Ranki, J. Vrbka, K. Valaskova, J. Olah, Objectifying women's bodies in the workplace: Gender-based misconduct, egregious sexual pressure, and misogynistic practices, Contemporary Readings in Law and Social Justice 10, 71-78 (2018)

6. P.Aghion, X. Jaravel. Knowledge Spillovers, Innovation and Growth. Economic Journal, 125(583), 533-573. (2015) https://doi.org/10.1111/ecoj.12199

7. Yu. V. Selivanova. Proactive marketing in the development of the state literary Museum "XX century": exhibition direction of work. Management in the field of culture and media communications: innovative approaches and technologies: Materials of the III International scientific and practical conference. St. Petersburg, Russia, 219-223. (2016)

8. G. G. Bogomazov, D. A. Davydova. Sphere of culture as an object of study of economic science. St Petersburg University Journal of Economic Studies, 33, (3), 415432 (2017) 
9. V.A. Kolycheva. Profitable and losing art-investments: a statistical analysis of the profitability. St Petersburg University Journal of Economic Studies, 33 (4), 641657. (2017) https://doi.org/10.21638/11701/spbu05.2017.407.

10. F. F. Rybakov Culture and market relations. Russian economic journal, 12, .68-74. (1992)

11. V. Pashkus, N. Pashkus, M. Pashkus. Strategic positioning of territories in the global economy: brand development in accordance with the matrix of competitiveness of territories. Globalization and its Socio-Economic Consequences. 18th International Scientific Conference Proceedings. Zilina, Rajecke Teplice, Slovak Republic, 27272734. (2018)

12. K. Almakuchukov et al. Features of the Global Sphere of Culture in the Modern World. Problems of the modern economy, 1, 178-181 (2019)

13. N.A.Pashkus, M.V.Pashkus. Features of the Breakthrough Positioning of Art Objects. Marketing MBA. Marketing management firms. 7 (1), 104-123. (2016)

14. N. A. Paskus et al. Strategic marketing: tutorial and workshop for undergraduate and graduate. Urait:Moscow. (2016).

15. S.Pusa, L. Uusitalo. Creating Brand Identity in Art Museums: A Case Study. International Journal of Arts Management, 17 (1), 18-30 (2014)

16. Y. V. Selivanova. The Modern Russian artist's book as an object of Museum storage: to statement of a problem. Problem of Museology, 2, 125-136. (2017)

17. Zh. A. Aliaskarova. A New economy: from domination intangible assets for brand development. Marketing MBA. Marketing management firms, 8 (3), 36-47. (2017)

18. N. A. Pashkus, M. V. Pashkus. Investment strategies in the art market: evaluation features and approaches to it. Strategic management, 4, 294-304. (2013)

19. B. Anderson Imagined communities. Reflections on the origins and spread of nationalism. Canon Press-C, Moscow. (2001)

20. J. Mei, M. Moses Art as an Investment and the Underperformance of Masterpieces. American Economic Review, 92 (5), 1656-1668. (2002)

21. A. I. Vodopianova, L. A. Leonova, A.E. Novak. The art market: Features of investing in works of pictorial art. St Petersburg University Journal of Economic Studies, 34 (1), 95-112. (2018)

22. A.A. Kirillovskaya, et al The Newest Economic Policy, Government Regulation of the Economy and Economic Security. Globalization and its Socio-Economic Consequences. 16th International Scientific Conference Proceedings. Zilina, Rajecke Teplice, Slovak Republic, 870-875. (2016)

23. A. Grinko, A. A. Shevtsova. "Reanimating Anderson": Museum and map in the formation of modern identities. Cultural journal, 1(19), 9. 2015

24. M. V. Pashkus. Analysis of investment attractiveness of art market objects. Marketing MBA. Marketing management firms, 7 (3), 18-39. (2016)

25. V. A. Kolycheva. Art Market: theoretical and economic analysis. (Prospect, Moscow, 2014)

26. J. L.Nueno, J. A. Quelch. The mass marketing of luxury. Business Horizons, 41 (6), 61-68. (1998)

27. R. B.Ekelund, R. W. Ressler, J. K.Watson The "Death-Effect" in Art Prices: A Demand-Side Exploration. Journal of Cultural Economics, 24 (4), 283-300. (2000) 
28. O.Ashenfelter, K. Graddy Auctions and the Price of Art. Journal of Economic Literature, 41(3), 763-787. (2003)

29. A. B. Kosterina. Art and Commerce: textbook. (Publishing house of Herzen University, Ekaterinburg, 2008)

30. S. Wang. Turning Right/Turning Left? A Neoclassical Socioeconomic Query of the Arts Signaled by Museum and Branding in Finland. Journal of Arts Management Law and Society, 46(4), 164-176. (2016) 